Using Cognitive Model in-Group Work in Improving the Social Skills for Gifted Children

\author{
Mahmoud M. Mounier (Ph.D.) \\ Department of Group Work
}

The Higher Institution of Social Work, Alexandria 


\section{Using Cognitive Model in-Group Work in Improving the Social Skills for Gifted Children}

Mahmoud M. Mounier (Ph.D.)

Department of Group Work

The Higher Institution of Social Work, Alexandria

\section{Abstract:}

The purpose of this study was to determine the feasibility of using a cognitive model in-group work to improve the social skills for gifted children. Sixty-four children were randomly assigned to an experimental group and a control group (32 children in each group). Thirty-two children's parents of the experimental group were also involved. Each group was asked to complete two forms of measurement. Firstly, a measurement was used to assess the utility of a cognitive model in group work to improve the social skills of gifted children. Secondly, another measurement assessed the parents observations of their children at home during the experiment. Children in the experimental group were introduced to the cognitive model to build their social skills. The intervention lasted for 14 weeks. Children in the experimental group and the control group completed the measures again. The results suggested that using a cognitive model is an effective method to improve the social skills for gifted children.

Keywords: cognitive model, social skills, gifted children.

\section{Introduction:}

The purpose of the present study determined the feasibility of using a cognitive model in-group work to improve gifted children's social skills. This approach focused on four areas:

- Build (Improve or build) the gifted children's knowledge about social skills.

- Build the gifted children's verbal communication skills.

- Build the gifted children's non- verbal communication skills.

- Build the gifted children's confidence to use their social skills.

The research question arose from an increased interest about gifted children in Egypt. This heightened interest relates to the expanding technological advances that are occurring in the country. Concomitant with these changes, there is a recognition that social skills hold an increased importance in such developments. Therefore, gifted students, who are likely to hold these kinds of positions, need to 
further develop their social skills. Egypt's concern regarding gifted children began during the early sixties of the last century (Boutros Hafez, 1997).It arose both due to concern for gifted students and the need to assist them to excel academically. He established a school for gifted children at Ain Shams. It was followed by the issuance of Ministerial Decree No. 114 to create classes for academically gifted students in secondary schools. This accounted for approximately five percent of the students. There was a commitment that community institutions and families of these children shared a responsibility for them to excel academically (Adel Abo Elez Ahmed, 2000). It also was argued that society should devote special resources to the development of these gifted young people in the twenty-first century. It was also believed that the goals of education for gifted students would further talent development, maximize young people's opportunities for self-fulfillment and increase society's reservoir of creative problem solvers.(Renzulli, Joseph S,2012,PP.150-159)..

Since this work began, the identification of gifted children has led to various lines of research into superior intelligence. In addition, there are numerous studies focused on understanding the cognitive functioning of these children. (Laurence Vaivre-Douret, 2011). Frequently, parents request advice on how to help their gifted son or daughter learn to get along better with others. Many otherwise extraordinarily bright and gifted young children display a range of deficits in the area of social skills such as with peers, siblings and even adults,. These social skill problems among the gifted are not as uncommon as people like to believe. Intellectually precocious and highly talented children are not necessarily equipped with advanced, or even age-appropriate, social skills. This fact comes as a great surprise to many of the parents of gifted children (Steven Pfeiffer, 2011). Gifted children demonstrate human potential and achievement that far exceed what would be expected based upon their chronological age. A myriad of research studies have explored whether or not gifted children demonstrate greater difficulties in the areas of social and emotional adjustment compared with their nongifted peers (Kimberly A Mula and others no date). It is important to identify opportunities for gifted children to spend time with likeminded peers on a regular basis so they have opportunities to hone their social skills. They need to find peers who share the same 
interests, style, level of knowledge, and sensibilities (National Association for Gifted Children, no date).

This researcher saw the importance of improving the children's social skills through a professional intervention program using a cognitive model component in group work through cognitive restructuring, self-inoculation training; open discussion; watching educational films; role-playing; focus on body language; and listening to stories. There are many ways to help the children to improve their social skills such as explaining the basics of good manners and kindness and finding group activities and sports that help bolster social skills (Kirsten Schuder, no date).

The present study was different from the previous studies because it focuses on the development of social skills for gifted children rather than their intellectual abilities. These skills include: how to communicate effectively with others; build confidence; practice these new skills without shame; the ability to debate; how to listen and expresses opinions; understand and use the of body language. The researcher was interested in parents' observations on the success of their children acquiring increased social skills.

\section{Methodology:}

Hypothesis: The main hypothesis for the present study was to explore whether or not there was a positive relationship between using the cognitive model in-group work for improving the social skills of gifted children.

\section{Sub hypotheses:}

1. There is a positive relationship between using a cognitive model ingroup work for building gifted children's knowledge of social skills.

2. There is a positive relationship between using a cognitive model ingroup work for building gifted children's verbal communications skills.

3 . There is a positive relationship between using a cognitive model ingroup work for building gifted children's non-verbal communication skills.

4. There is a positive relationship between using cognitive model ingroup work for building gifted children's confidence in using social skills.

Participants: The present study was a quasi-experimental study of 64 gifted children, who were randomly assigned to an experimental group 
and a control group (32 gifted children in each group. They were between the ages of 10-14 years old, males and females, and attended the Exploratory Center for Science and Technology.

Procedures: The present study applied steps of a cognitive model to the group work setting. The present study also used a measurement for gifted children regarding cognitive model components in-group work to improve social skills for gifted children for the experimental and control groups. The researcher took into account the terms of homogeneity between the experimental and control groups in terms of types (boys and girls- students in the same levels at the end of the primary and preparatory level - converged age). The groups occurred at the Exploratory Center for Science and Technology in Alexandria

Intervention: The intervention program occurred for 14 weeks (June to the middle of September 2016). The group meetings were held once a week for 2 to 2.5 hours. The first month of the program's meetings were about the building the gifted children's knowledge of social skills. This training involved defining the concept of social skills, exploring meanings of behavior of verbal and non-verbal communication, and the ability to express emotional and social awareness.

Positive role models were presented, as well as stories to increase their knowledge about social skills. In the second month, meetings focused on building the gifted children's verbal and nonverbal communications skills. This segment of the training included the following: defining verbal and non- verbal communication skills; and the effect that an individual's communication has on others. Another focus was on building the children's skills through discussions, role-plays , movies, developing personal skills, exchanging information and experiences and presenting positive role models from some children who supported their peers. The meetings during the third month continued with the aforementioned training areas. The children also showed their paintings, poems, and created possible solutions related to some of their local community issues To build their confidence and their ability to deal with others using social skills, the researcher relied on many of the strategies of group work to improve their social skills (see table 9). The researcher ended the work gradually with the gifted children's group. These children presented some of their artwork, technological, theatrical and poetic activities, to 
their teachers at the center as well as their parents. They were presented with certificates of appreciation.

\section{Measures:}

The questionnaire of using a cognitive model in-group work to improve the social skills for gifted children has four components as shown below: building the social skills for children, which contains 28 items building the children's verbal communications skills, which contain 22 items, building the children's non-verbal communications skill, which contains 19 items, and building the children's confidence to use the social skills, which contains 29 items ,The questionnaire used a Likert Scale The scale included the following options: Agree $=3$; Almost agree $=2$; and Not agree $=1$. The questionnaire was retested after 15 days.

Table 1: The values of reliability coefficients for gifted children group of the dimensions of the questionnaire

\begin{tabular}{|c|c|c|c|c|}
\hline $\begin{array}{l}\text { Dime } \\
\text { nsions }\end{array}$ & Questionnaire's component & $\begin{array}{l}\text { Cronbach's } \\
\text { Alpha }\end{array}$ & $\begin{array}{c}\text { Standardized } \\
\text { Cronbach's } \\
\text { Alpha }\end{array}$ & Validity \\
\hline 1 & $\begin{array}{l}\text { Build the gifted children's } \\
\text { knowledge about social skills. }\end{array}$ & 0.949 & 0.947 & 0.900 \\
\hline 2 & $\begin{array}{l}\text { Build the gifted children's verbal } \\
\text { communication skills }\end{array}$ & 0.932 & 0.932 & 0.869 \\
\hline 3 & $\begin{array}{l}\text { Build the gifted children's non- } \\
\text { verbal communication skills }\end{array}$ & 0.906 & 0.906 & 0.821 \\
\hline 4 & $\begin{array}{l}\text { Build the gifted children's } \\
\text { confidence to use their social skills }\end{array}$ & 0.941 & 0.941 & 0.885 \\
\hline
\end{tabular}

Source: the questionnaire collected from the research sample.

The questionnaire of parents, who observed their children at home during the daily life situations, to be sure they demonstrated the social skills, had 29 items and it is divided into a Likert Scale. The scale was a follows: $($ Always $)=3 ;($ Sometimes $)=2 ;($ Never $)=1$. The questionnaire was applied on a sample of gifted children's parents from the exploratory center for Science and Technology who were randomly selected from total gifted children's parent group and then the questionnaire was re-tested after 15 days. 
Table 2: The values of reliability coefficients for gifted children's parents group of the questionnaire.

\begin{tabular}{||c||c||c||c||c||}
\hline \hline Dimension & questionnaire 's component & $\begin{array}{c}\text { Cronbach's } \\
\text { Alpha }\end{array}$ & $\begin{array}{c}\text { Standardized } \\
\text { Cronbach's } \\
\text { Alpha }\end{array}$ & Validity \\
\hline \hline 1 & $\begin{array}{l}\text { Gifted children's confidence } \\
\text { to use the social skills. }\end{array}$ & 0.934 & 0.933 & 0.872 \\
\hline
\end{tabular}

Source: the questionnaire collected from the research sample.

\section{Data analysis:}

Reliability test: This technique compares the average of grades of the students before and after completing the intervention program based on the same balance for distributing the test grades, and it is known as the terminals comparison as it is based on the strong terminal that we call strong balance power terminal and weak balance power that we call weak balance power terminal, that's mean students who get high grades in the application after the interventions, they have a strong balance power terminal and vice versa (Morsi, 2013, p.83-86This section is unclear.

Analysis of variance (ANOVA) or Fisher test (F-test) was used for comparison of a one way ANOVA used for comparison between more than two means:

\begin{tabular}{||c||c||c||c||c||c||}
\hline $\begin{array}{c}\text { Variance } \\
\text { Sources }\end{array}$ & $\begin{array}{c}\text { Sum } \\
\text { Square }\end{array}$ & $\begin{array}{c}\text { Degree } \\
\text { of free }\end{array}$ & $\begin{array}{c}\text { Mean of sum } \\
\text { square }\end{array}$ & \multicolumn{2}{|c||}{ F. ratio } \\
\hline \hline $\begin{array}{c}\text { Between groups } \\
\text { (Regression) }\end{array}$ & $\begin{array}{c}\text { RSS or } \\
\text { BSS }\end{array}$ & $\mathrm{k}-1$ & MSR=SSR/k-1 & MSR & BMS \\
\hline $\begin{array}{c}\text { Within groups } \\
\text { (Error) }\end{array}$ & $\begin{array}{c}\text { ESS or } \\
\text { WSS }\end{array}$ & $\mathrm{n}-\mathrm{k}$ & MSE=SSE/n-k & MSE & WMS \\
\hline \hline Total & TSS & $\mathrm{n}-1$ & & & \\
\hline
\end{tabular}

- Chi Squared test: Is any statistical hypothesis test where in the sapling distribution of the test statistic a chi-squared distribution when the null hypothesis is true.

- Kruskal-Wallis: This non-parametric test was used to test two independent samples or more, or the same sample in different times. This test was utilized to measure the impact of a particular training program. The data used in this analysis are ordinal ranks.(Dominic Salvatore,1984, pp 151-160) 


\section{Results}

The findings of the experiment yielded positive results related to using a cognitive model with gifted children in-group work, and building the gifted children's knowledge of social skills: The analysis resulted in significant changes of statistical proof at the probability level of 0.01 and 0.05

There was a positive relationship shown between using a cognitive model in-group work and building the gifted children's verbal communications skills. Which resulted in significant changes at the probability level of 0.01 and 05 .

There was a positive relationship between using a cognitive model in-group work and building the gifted children's non-verbal communications, which resulted in significant changes at the probability level of 0.01 and 0.05 .

There is a positive relationship between using a cognitive model in-group work and building the gifted children's confidence to use the social skills: which verified significant changes at the probability level of 0.01 and 0.05 .

Analysis of significant difference between the views of the research sample of parents before and after the intervention with their gifted children yielded resulted significant findings at the probability level 0.01 and 0.05 for all sentences.

(The findings section does not discuss the implications of them. That is included in the discussion section of the paper).

\section{Discussion}

The study attempted to verify the feasibility of using a cognitive model in-group work to improve the social skills of gifted children. These findings are confirmed by research done Hillary Hettinger Steiner Ema and Martha Carr (2003). Their research indicated the necessity of including findings related to the developmental issues faced by gifted children. Other research that was conducted by Yacoub Fareed Alfarah (2016) indicated there were statistically significant differences among gifted students in their communication skills, due to gender and grade levels at school. Therefore, utilizing cognitive restructuring, self- inoculation training, the application face; and modifying the children's non-logical thought and incompatible behavior patterns are effective strategies with these children through the use of group work. Other strategies include open 
discussion, watching educational films, and role-playing, body language, listening to stories, self-expression, active participation, imagination, and mind-body connections. All of these approaches help to improve the gifted children's social skills. Thus, these children are better able to communicate clearly using a wide range of vocabulary that is appropriate for the setting following the group experience. This increased capacity is important since specialists theorize that the spoken word can be difficult for these children because they have the added task of translating the complex ideas in their heads into language that others can understand. This process can lead to abnormal hesitation when speaking, stuttering, and frustration on the part of the children. To help gifted children to develop good verbal communication skills, they need to be encouraged to think through what they are going to say before they say it. Providing them with a variety of ways to express themselves nonverbally is also significant.

Building gifted children's confidence to use their social skills is highly relevant. These skills include: the ability to stay calm in social situations; listening to others; the art of connecting; employing empathy with others' situations; knowing how to build rapport; knowing how, when and how much to talk about yourself; looking directly at others; and smiling.

\begin{tabular}{|c|c|c|c|c|c|c|c|c|}
\hline \multicolumn{9}{|c|}{ Table no(3) Comparisons between experimental and control group } \\
\hline \multirow{2}{*}{$\begin{array}{c}\text { The } \\
\text { components }\end{array}$} & \multicolumn{2}{|c|}{$\begin{array}{l}\text { Experimental } \\
\text { group pre-test }\end{array}$} & \multicolumn{2}{|c|}{$\begin{array}{c}\text { control group } \\
\text { pre-test }\end{array}$} & \multicolumn{2}{|c|}{$\begin{array}{l}\text { Experimental } \\
\text { group post-test }\end{array}$} & \multicolumn{2}{|c|}{$\begin{array}{c}\text { control group } \\
\text { post-test }\end{array}$} \\
\hline & Scores & $\begin{array}{l}\text { Likert } \\
\text { Scale }\end{array}$ & Scores & $\begin{array}{l}\text { Likert } \\
\text { Scale }\end{array}$ & Scores & $\begin{array}{l}\text { Likert } \\
\text { Scale }\end{array}$ & Scores & $\begin{array}{l}\text { Likert } \\
\text { Scale }\end{array}$ \\
\hline $\begin{array}{l}\text { The first } \\
\text { component }\end{array}$ & 1469 & 45.9 & 1714 & 53.6 & 2308 & 72.1 & 1715 & 1469 \\
\hline $\begin{array}{l}\text { The second } \\
\text { component }\end{array}$ & 1194 & 37.3 & 1373 & 42.9 & 1844 & 57.6 & 1375 & 1194 \\
\hline $\begin{array}{l}\text { The Third } \\
\text { component }\end{array}$ & 1052 & 32.9 & 1176 & 36.8 & 1547 & 48.3 & 1216 & 1052 \\
\hline $\begin{array}{l}\text { The fourth } \\
\text { component }\end{array}$ & 1568 & 49.0 & 1649 & 51.5 & 2369 & 74.0 & 1658 & 1568 \\
\hline
\end{tabular}




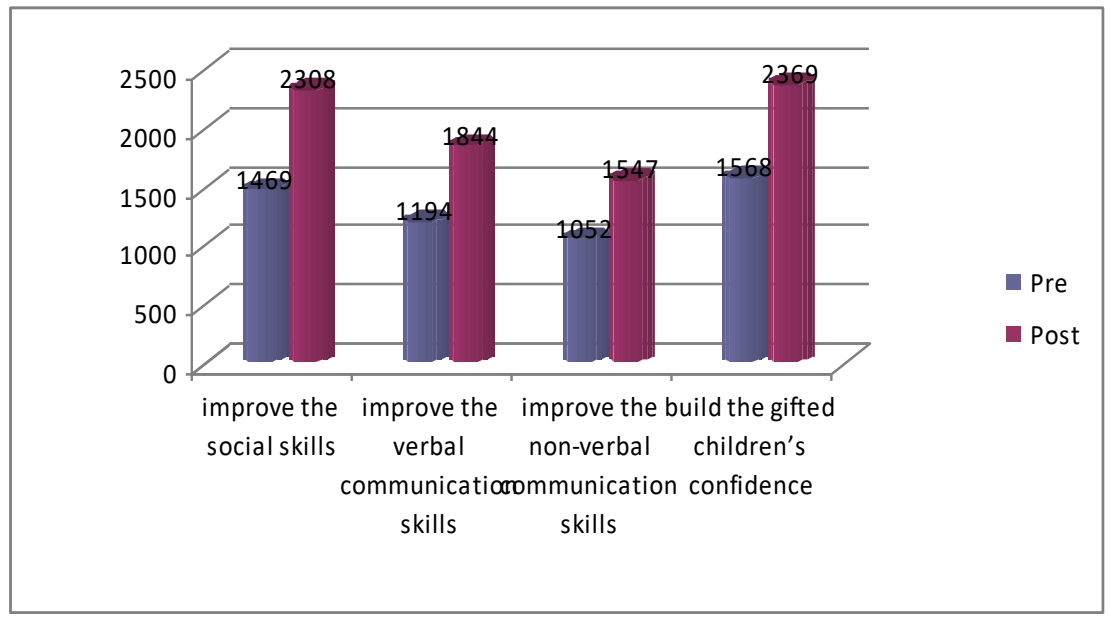

The findings indicated differences between the gifted children's parents observations in pre and post- test the change in the scores are due to the intervention program.

\section{Limitations:}

The researcher has to point out to that the study's results cannot be generalized as they belong to the quasi-experimental studies and findings are indicators of the program's success. Challenges occurred during the program's implementation such as the absence of four children in the second group meeting. This issue was solved by asking the children who attended the meeting to inform those who didn't attend about the information that they missed.

\section{Implications for Future Study:}

The researcher believes that continued work with these children is imperative. Social work has an important instrumental role in developing such group work programs for gifted children.

\section{Reference}

- Adel Abo Elez Ahmed, (2000), Jordon, Visualize a proposal for a science curriculum for superior, invest for the future of education the best in the Arab world, the best investment for the future of the Arab Second Scientific Conference for Giftedness, creative education, the first part.

- Botroushafez, (1997). Cairo, Study for self-esteem of gifted children with innovative capabilities, Second Scientific Conference at the faculty of kindergarten. 
- Dai, David Yun; Renzulli, Joseph S, (2008). Snowflakes, Living systems, and the mystery of giftedness, Gifted Child Quarterly, v52 n2 p114-130, Journal article, Retrieved from http://eric.ed.gov/?id=EJ789297

- Dominic Salvatore (1984), ,Statistics and economics, macrohaill, Al-Ahramlibrary press..

- Dorothy Sisk, (1975). "Communication skills for the gifted, gifted child quarterly 19(1), DOI: 10.1177/001698627501900111, Retried from https://www.researchgate.net/publication/234660812_Communicat ion_Skills_for_the_Gifted

- Hillary Hettinger Steiner, Martha Carr, Cognitive development in gifted children: toward a more precise understanding of emerging differences in intelligence, Educational Psychology Review, September 2003, Volume 15, Issue 3, pp 215-246, Article DOI: 10.1023/A:1024636317011, retrieved from http://link.springer.com/article/10.1023/A:1024636317011

- http://www.theoldschoolhouse.com/product/communication-skillsand-your-gifted-child/

- JoJoTabares, Communication skills and your gifted child, retrieve from

- Kimberly A Mula and others, gifted children and social relationship, Retrieved from: http://afgfamily.com/gifted-childrenand-social-relationships/

- Kirsten Schuder,Mental Health Counseling, Retrieved from http://m.wikihow.com/Improve-Social-Skills-in-Children.

- Laurence Vaivre-Douret,(2011), International Journal of Pediatrics, Volume 2011 (2011), Article ID 420297, 14 pages, http://dx.doi.org/10.1155/2011/420297, Retrieved from https://www.hindawi.com/journals/ijpedi/2011/420297/

- Mark Tyrrell, 6 Key Social Skills, Retrieve from http://www.selfconfidence.co.uk/articles/6-key-social-skills/

- Morsi.(2013). Social Statistics, Alexandria,the modern university Office press

- National Association for Gifted Children, retrieved from : www.nagc.org/resources-publications/resources-parents/socialemotional-issues/social-skills 
- Peter Flom, Developing social Skills in Gifted Children, retrieve from https://globalgtchatpoweredbytagt.wordpress.com/2016/04/19/deve loping-social-skills-in-gifted-children/

- Renzulli, Joseph S,( 2012). Reexamining the role of gifted education and talent development for the 21st century: A Four-Part Theoretical Approach, Journal Articles; National Association for Gifted Children , Vol 56, Issue 3, First Published , pp. 150159,Retrieved http://journals.sagepub.com/doi/full/10.1177/0016986212444901.

- Rick and Teena Kamal, Special needs of gifted children, retrieve from http://www.specialneeds.com/children-and-parents/generalspecial-needs/special-needs-gifted-children

- Sarah Jane Henderson, Integrating oral communication skills into everyday learning, Retrieve from https://languageandliteracytheoryandpractice.wikispaces.com/Integ rating+Oral+Communication+Skills+into+Everyday+Learning

- Steve Haberline, How to teach social skills to gifted kids, Retrieve from http://www.educationworld.com/blog/how-teach-socialskills-gifted-kids

- Steven Pfeiffer,(2011). Raising a well-adjusted gifted child: the value of promoting social intelligence, Retrieved from : http://sengifted.org/raising-a-well-adjusted-gifted-child-the-valueof-promoting-social-intelligence/

- VanTassel-Baska, J.,(2012), Tips for parents: nurturing verbal ability in gifted learners, Davidson Institute for Talent Development, Retrieved from http://www.davidsongifted.org/Search-Database/entry/A10747

- Yacoub Fareed Alfarah, (2016)Communication skills among gifted students in Jordan , 1 Jun 2016, Journal, Volume 28, 2013 Issue $1-2$ Retrieve from http://www.tandfonline.com/doi/abs/10.1080/15332276.2013.1167 8420

Table no (4) The Professional intervention program

\begin{tabular}{||c||c||c||c||c||c||c||c|}
\hline \hline Sub- objectives & $\begin{array}{c}\text { Topics and } \\
\text { activities of } \\
\text { professional } \\
\text { intervention } \\
\text { program }\end{array}$ & Strategies & Techniques & $\begin{array}{c}\text { Cognitive } \\
\text { The role of } \\
\text { the social } \\
\text { group } \\
\text { gresearcher( } \\
\text { components } \\
\text { strategies and } \\
\text { professional } \\
\text { roles of the } \\
\text { group work }\end{array}$ & Participants \\
\hline
\end{tabular}


The Egyptian Journal of Social Work (EJSW)

Print ISSN: 2356-9204 Online ISSN: 2356-9212

http://ejsw.journals.ekb.eg

Vol 4, Issue 1, June 2017

\begin{tabular}{|c|c|c|c|c|c|c|c|c|}
\hline $\begin{array}{l}\text { Build the gifted } \\
\text { children's } \\
\text { knowledge } \\
\text { about social } \\
\text { skills }\end{array}$ & $\begin{array}{l}\text {-Present the } \\
\text { intervention } \\
\text { program and its } \\
\text { goals, pre-test } \\
\text { defining the } \\
\text { concept of social } \\
\text { skills, behavior, } \\
\text { verbal and non- } \\
\text { verbal } \\
\text { communications, } \\
\text { the ability to } \\
\text { express emotional } \\
\text { and social, } \\
\text { awareness of } \\
\text { signals and body } \\
\text { expressions, and } \\
\text { the ability to self- } \\
\text { control, also } \\
\text { include proficiency } \\
\text { in the performance } \\
\text { of soc5ial activities }\end{array}$ & $\begin{array}{l}\text { Education } \\
\text { and } \\
\text { edification }\end{array}$ & $\begin{array}{c}\text { Education, } \\
\text { enlighten and } \\
\text { Exchange ideas }\end{array}$ & $\begin{array}{l}\text { Expert, } \\
\text { leader, } \\
\text { professional } \\
\text { and } \\
\text { teacher }\end{array}$ & $\begin{array}{l}\text { The } \\
\text { researcher } \\
\text { and } \\
\text { teachers } \\
\text { from the } \\
\text { center }\end{array}$ & $\begin{array}{l}\text { Cognitive } \\
\text { restructuring, } \\
\text { Self- } \\
\text { inoculation } \\
\text { training, the } \\
\text { application } \\
\text { face; painting, } \\
\text { Watching the } \\
\text { educational } \\
\text { films, Story, } \\
\text { abstract arts, } \\
\text { meaningful } \\
\text { singing }\end{array}$ & $\begin{array}{c}\text { First } \\
\text { month }\end{array}$ & $\begin{array}{c}\text { From } \\
2 \text { hrs } \\
\text { To } \\
2.5 \\
\text { hrs } \\
\text { Each }\end{array}$ \\
\hline $\begin{array}{l}\text { Build the gifted } \\
\text { children's } \\
\text { verbal and non- } \\
\text { verbal } \\
\text { communication } \\
\text { skills }\end{array}$ & $\begin{array}{l}\text { defining the verbal } \\
\text { communication } \\
\text { skills }\end{array}$ & $\begin{array}{l}\text { Education, } \\
\text { convince } \\
\text { and } \\
\text { training }\end{array}$ & $\begin{array}{c}\text { Communication, } \\
\text { clarify, } \\
\text { explanation, } \\
\text { and enlighten }\end{array}$ & $\begin{array}{l}\text { Guide, } \\
\text { expert and } \\
\text { teacher }\end{array}$ & $\begin{array}{l}\text { The } \\
\text { researcher } \\
\text { and } \\
\text { specialist in } \\
\text { arts }\end{array}$ & $\begin{array}{c}\text { present some } \\
\text { positive models } \\
\text { and storytelling, } \\
\text { role play, } \\
\text { workshops, } \\
\text { distributing } \\
\text { small groups }\end{array}$ & $\begin{array}{l}\text { Second } \\
\text { month }\end{array}$ & $\begin{array}{c}\text { From } \\
2 \text { hrs } \\
\text { To } \\
2.5 \\
\text { hrs } \\
\text { Each }\end{array}$ \\
\hline $\begin{array}{l}\text { Build the gifted } \\
\text { children's } \\
\text { confidence to } \\
\text { use their social } \\
\text { skills }\end{array}$ & $\begin{array}{l}\text { showing their } \\
\text { paintings, present } \\
\text { their poems, } \\
\text { subscribe through } \\
\text { small groups to } \\
\text { prepare some } \\
\text { solutions of the } \\
\text { community issues, } \\
\text { end the work with } \\
\text { the gifted children } \\
\text { group gradually }\end{array}$ & $\begin{array}{l}\text { Education } \\
\text { and } \\
\text { training }\end{array}$ & $\begin{array}{c}\text { Education, } \\
\text { Exchange ideas } \\
\text { Support, clarify } \\
\text { and enlighten }\end{array}$ & $\begin{array}{l}\text { Guide, } \\
\text { helper, } \\
\text { expert and } \\
\text { teacher }\end{array}$ & $\begin{array}{l}\text { The } \\
\text { researcher }\end{array}$ & $\begin{array}{c}\text { showing their } \\
\text { paintings, } \\
\text { present their } \\
\text { poems, } \\
\text { subscribe } \\
\text { through small } \\
\text { groups to } \\
\text { prepare some } \\
\text { solutions of the } \\
\text { community } \\
\text { issues, group } \\
\text { discussion } \\
\text { workshop, } \\
\text { meaningful } \\
\text { singing }\end{array}$ & $\begin{array}{c}\text { Third } \\
\text { month } \\
+2 \\
\text { weeks } \\
\text { from } \\
\text { the } \\
\text { fourth } \\
\text { month }\end{array}$ & $\begin{array}{c}\text { From } \\
2 \text { hrs } \\
\text { To } \\
2.5 \\
\text { hrs } \\
\text { Each }\end{array}$ \\
\hline
\end{tabular}

